\title{
Efficiency of macro- and micronutrients in spring wheat protection system
}

\author{
Vyacheslav Timofeev* \\ Tyumen Scientific Center of the Siberian Branch of the Russian Academy of Sciences, 86 Malygina \\ St., 625026 Tyumen, Russia
}

\begin{abstract}
The work presents studies of preparative laboratory forms of preparations containing nanoparticles of macro- and micronutrients by inclusion of stabilizers and solution modifiers on growth and development of spring triticale plants in the first phases of ontogenesis and spring wheat under field conditions. The preparations and their rates positively affecting germination energy, germination rate with the effect of $4-6 \%$ and plant growth under the influence of preparations on daily seedlings were isolated in laboratory studies. The preparations $\mathrm{Mn}, 10 \mathrm{ml} / \mathrm{t}, \mathrm{Ca}, 10 \mathrm{ml} / \mathrm{t}, \mathrm{Mo}, 50$ $\mathrm{ml} / \mathrm{t}$, Titan $\mathrm{M}, 50 \mathrm{ml} / \mathrm{t}$, biogenic $\mathrm{Fe}, 5 \mathrm{ml} / \mathrm{t}$ had a positive effect on energy and germination, while the preparations $\mathrm{Mn}, 10 \mathrm{ml} / \mathrm{t}, \mathrm{Ca}, 10 \mathrm{ml} / \mathrm{t}, \mathrm{Mo}, 50$ $\mathrm{ml} / \mathrm{t}$, Titan M, $50 \mathrm{ml} / \mathrm{t}$, biogenic Fe, $5 \mathrm{ml} / \mathrm{t}$, Bor $5 \mathrm{mg} / \mathrm{g}+\mathrm{GC}(10 \%)$ had a positive effect on sprout length, $1 \mathrm{ml} / \mathrm{t}$, Potassium, $1000 \mathrm{ml} / \mathrm{t}$ of which the variants with Boron $5 \mathrm{mg} / \mathrm{g}+\mathrm{GC}(10 \%), 1 \mathrm{ml} / \mathrm{t}$, Potassium, $1000 \mathrm{ml} / \mathrm{t} \mathrm{had}$ the greatest and significant effect, where the increase in sprout length was $1.0-3.2 \mathrm{~cm}$ or $7.8-25 \%$, mass $0.5-1.4 \mathrm{~g}$ or $6-8 \%$. In field studies, we evaluated the use of biogenic iron in the plant protection system as a stimulant in the treatment of seeds together with a seed dressing and plants during the growing season. The effect of the preparation on the development of plants contributing to increased yield was determined, especially the treatment of wheat plants in the earing phase, which provided an increase of $0.5 \mathrm{t} / \mathrm{ha}$.
\end{abstract}

\section{Introduction}

In the organization of cultivation technology and crop protection from harmful factors (pests, diseases), presowing seed preparation has a significant impact on improving economic efficiency and is one of the easiest ways to improve the quality of seed [1]. The use of fungicides reduces the number of affected plants during the growing season, but has a retardant effect on growth functions; various substances of biological and chemical origin, can be used to stimulate growth. The use of microfertilizers in pure form and together with a chemical dressing promotes an increase in germination, root growth, germination and growth enhancement in the first phases of ontogenesis [2-5] in some studies the stimulation of growth processes was expressed by a change in seedling length, and in others by an increase in roots, indicating differences in the direction of action of drugs [6-8].

\footnotetext{
*Corresponding author: Timofeev_vn2010@mail.ru
} 
The combined use of reduced norms of tebuconazole with licorice root extract and arabinogalactan provided high efficiency, the use of chelated forms of trace elements did not always have a positive effect, also the prolonged use of trace elements leads to inhibition of growth processes compared to seed treatment alone [6, 9, 10]. Complex micronutrient fertilizers during seed treatment have a significant effect on the formation of the leaf surface [11]. In modern times trying to reduce a substance or particle to nanoparticles to improve the conditions of penetration and delivery to the plants needed substances, so the authors consider nanoparticles as potential agents for agriculture, such as fertilizers, growth enhancers, pesticides, when applied in non-toxic concentrations can promote seed germination, accelerate plant growth, increase yields and protect plants from environmental influences [12, 13].

Micronutrient compositions are used both in seed treatment and in important next phases of plant ontogenesis in combination with pesticides (tillering, beginning of earing). Thus, according to the researchers' data, foliar feeding with chelated iron compounds contributed to the increase of yield structure indices $[14,15]$. Application of macro- and micronutrients and growth regulators positively affects the growth dynamics of spring wheat, especially the use of microfertilizers during the growing season in mixture with nitrogen $[16,17]$. Some authors emphasize the positive effect of foliar feeding with zinc and copper chelates on grain quality $[18,19]$. The productivity of agricultural plants, is a process of biomass accumulation, which is more closely correlated with the assimilative surface area of plants, which is definitely regulated by plant nutrition [20]. The aim of the research is to determine the most active preparative forms containing macro and micronutrients used in seed treatment and during vegetation to stimulate growth and increase crop yield.

\section{Materials and Methods}

Studies were carried out under laboratory and field conditions SRIA for NTUR - Branch of Tyumen Scientific Centre SB RAS, Moskowskiy, Tyumen district, Tyumen region, Northern forest-steppe zone. The soil of the experimental plot belongs to the dark gray forest subtype, with a granulometric composition of heavy loam. The content of nitrate nitrogen in the study soil is low $(1.36-2.38 \mathrm{mg} / 100 \mathrm{~g}$ soil), phosphorus is average (8.25 $14.1 \mathrm{mg} / 100 \mathrm{~g}$ soil $)$, potassium is above average $(6.65-8.9 \mathrm{mg} / 100 \mathrm{~g}$ soil $)$, the reaction of soil solution is slightly acidic (5.1-6.0). The counts and observations were performed according to the standard methodological guidelines adopted in the GosSortset, crop production and plant protection. Phytoexpertise of seeds, was carried out by roll method 2 samples of 50 grains each. The assessment of seed infestation by various pathogens, was evaluated on the 7 th day. The development and prevalence of common root rot were determined in the tillering phase and before harvesting. The development of aerogenic infections (brown leaf rust, septoriosis, powdery mildew) was counted from tillering to milk ripeness and determined by universal scales of plant infestation. Yield was taken into account by the method of continuous threshing with harvester Sampo 130, were brought to standard moisture content and purity according to GOST 1386.5-93 and 30483-97. Determination of grain quality parameters was carried out in the center of analytical studies and technological evaluation of grain according to GOST 12042-80, GOST 10840 - 64, GOST 13586.1-68. Under laboratory conditions, a comparative assessment and selection of the most positive effect on energy, germination and growth functions of macro and micronutrient solutions (nitrogen, phosphorus, potassium, calcium, magnesium, molybdenum, boron and their mixtures, determination of the effect was carried out in Petri dishes, wet rolls and sowing seeds with daily germination after treatment with preparations of 20 pcs of seeds per cup in 5 replications. The samples were taken in accordance with 
GOST 12038-84. Seeds of agricultural crops. Methods of analysis [21]. Sprout length, root length, weight of vegetative organs, reduction of fungi on seeds were taken into account. Seeds of spring wheat Grenada and spring triticale Ukro were used in the experiment. Biogenic iron hydroxide (ferrihydrite) produced by Krasnoyarsk Research Center SB RAS in the system of protection of spring wheat was evaluated under field conditions, that is comparative evaluation of application in combination with chemical protectants and in mixture with herbicides and fungicides during the corresponding development phases, its effect on the growth functions of wheat plants, reduction of diseases on seeds and root system during vegetation, yields. Statistical data processing using Excel program.

\section{Results and discussion}

In laboratory studies, the results of positive, neutral and negative effects of the application of preparations containing nanoparticles from 10-40 nm of macro- and micronutrients, were obtained. More than 20 preparations and their mixtures with different rates of application per $100 \mathrm{~g}$ of seeds, were used in the experiment. Seed treatment with ready preparative forms took place 1 hour before seeding, the drug rate was calculated as for standard presowing treatment of seeds (drug rate +101 of water per $1 \mathrm{t}$ of seeds). Used mixtures with the content (potassium + nitrogen + silicon + iron + calcium + titanium) of them more positive effect on germination showed variant № 1 slightly exceeding the control, but within the range of variation of the possible difference. Copper at a solution rate of $5 \mathrm{ml} / \mathrm{t}$ had an effect on germination, and higher rates reduced energy and germination indices; such effects were also observed for preparations with zinc, boron, and a mixture of readymade phosphorus + potassium with the stabilizer PVP (polyvinylpyrrolidone) + Ag-C modifier and nitrogen + phosphorus + PVP + Ag-C modifier. Positive effect on the germination energy of triticale seeds showed variants with $\mathrm{Cu}, \mathrm{Mn}, \mathrm{Mo}$, biogenic Fe, Titan $\mathrm{M}$, where the increase in growth energy was $4-10 \%$ of them the obvious high effect was by preparations Titan $\mathrm{M}$ in the rate of $500 \mathrm{ml} / \mathrm{t}(+7 \%)$, Mo molybdenum in the rate $10-50 \mathrm{ml}$ / $\mathrm{t}(+10+7 \%)$. As a result, out of 58 variations, 5 preparations with certain norms had a positive effect; the ability of the preparation to stay on the seed, the ability to overcome a certain protective layer, which adsorbs harmful substances and protects the embryo and get in the right dosage to stimulate germination and further growth of both physiologically weak seeds and normally developed ones, affects the effectiveness of the effect. Seed germination determined on day 7 in some variants was at the level of energy as the effect of drugs had a stimulating effect and a significant increase in germination was noted for the drugs $\mathrm{Ca}, \mathrm{Mn}$, at a rate of $5 \mathrm{ml} / \mathrm{t}(+4+5 \%)$ and Titan $\mathrm{M}$ at a rate of $500 \mathrm{ml} / \mathrm{t}$ and molybdenum $10-50 \mathrm{ml} / \mathrm{t}(+6+10 \%)$. For the other preparations there was a slight increase in germination or at the control level (Table 1).

Table 1. Energy and germination of seeds during treatment with preparations, \%.

\begin{tabular}{|c|c|c|c|}
\hline № & Option & Energy, \% & Germination, \% \\
\hline 1 & $\begin{array}{c}\text { Potassium-10 } \mathrm{ml}+\underset{\mathrm{ml} / \mathrm{t}}{\text { Nitrogen, }} 5 \mathrm{ml}+\mathrm{SiO}, 1 \mathrm{ml}+\mathrm{Ca}, 5 \\
\end{array}$ & $87(+1)$ & $89(+2)$ \\
\hline 2 & $\begin{array}{c}\text { Copper } 2-5 \mathrm{~mL} \text { ( }>\text { the norm reduces vigor and } \\
\text { germination) }\end{array}$ & $90(+4)$ & $90(+3)$ \\
\hline 3 & Mn 3-5 ml/t (>control level)) & $90(+4)$ & $91(+4)$ \\
\hline 4 & $\begin{array}{c}\text { Ca } 5-5 \mathrm{ml} / \mathrm{t}(>\text { the norm reduces vigor and } \\
\text { germination) }\end{array}$ & $88(+2)$ & $92(+5)$ \\
\hline 5 & Bio Fe-5 ml/t & $90(+4)$ & $90(+3)$ \\
\hline 7 & Titan M-50 ml/t & $90(+4)$ & $90(+3)$ \\
\hline
\end{tabular}




\begin{tabular}{|c|c|c|c|}
\hline 9 & Titan M-500 ml/t & $93(+7)$ & $93(+6)$ \\
\hline 10 & Mo $2-5 \mathrm{ml} / \mathrm{t}$ & $89(+3)$ & $90(+3)$ \\
\hline 11 & Mo $2-10 \mathrm{ml} / \mathrm{t}$ & $96(+10)$ & $97(+10)$ \\
\hline 12 & Mo $2-50 \mathrm{ml} / \mathrm{t}$ & $93(+7)$ & $93(+6)$ \\
\hline 13 & Zn 2000 ppm-10 ml/t (affected negatively) & $84(-2)$ & $85(-2)$ \\
\hline 14 & $\begin{array}{c}\text { Magnesium-20 mg/ml + PVP particles }<10 \mathrm{~nm}, 1-5 \\
\mathrm{ml} / \mathrm{t}\end{array}$ & $86(-)$ & $89(+2)$ \\
\hline 15 & 4 Bor-5 mg/g + GC (10\%), 1 ml/t (neutral effect) & $85(-1)$ & $86(-1)$ \\
\hline 16 & $\begin{array}{l}2 \mathrm{P}-10 \mathrm{mg} / \mathrm{g}+\mathrm{K} 12 \mathrm{mg} / \mathrm{g}+\mathrm{PVP} 15 \%+\mathrm{Ag}-\mathrm{C} 0.5 \mathrm{mg} / \mathrm{g} \text {, } \\
500 \mathrm{ml} / \mathrm{t}\end{array}$ & $86(-)$ & $86(-1)$ \\
\hline 17 & $\begin{array}{c}2 \mathrm{P}-10 \mathrm{mg} / \mathrm{g}+\mathrm{K} 12 \mathrm{mg} / \mathrm{g}+\mathrm{PVP} 15 \%+\mathrm{Ag}-\mathrm{C} 0.5 \mathrm{mg} / \mathrm{g} \\
1000 \mathrm{ml} / \mathrm{t}\end{array}$ & $86(-)$ & $88(+1)$ \\
\hline 18 & $\begin{array}{c}12 \mathrm{~N}-4 \mathrm{mg} / \mathrm{g}+\mathrm{P} 9 \mathrm{mg} / \mathrm{g}+\mathrm{PVP} 15 \%+\mathrm{Ag}-\mathrm{C} 0.5 \mathrm{mg} / \mathrm{g}, \\
10 \mathrm{ml} / \mathrm{t}\end{array}$ & $81(-5)$ & $84(-3)$ \\
\hline 19 & 5 Potassium- $10 \mathrm{ml} / \mathrm{t}$ & $79(-7)$ & $89(+2)$ \\
\hline 20 & 5 Potassium- $50 \mathrm{ml} / \mathrm{t}$ & $88(+2)$ & $89(+2)$ \\
\hline 21 & 5 Potassium- $100 \mathrm{ml} / \mathrm{t}$ & $88(+2)$ & $89(+2)$ \\
\hline 22 & 7 Nitrogen-100 ml/t (5 - $100 \mathrm{ml} / \mathrm{t}$, influential) & $83(-3)$ & $90(+3)$ \\
\hline 23 & Control (water)-6 ml & 86 & 87 \\
\hline & difference & $+-2,5$ & $+-2,8$ \\
\hline
\end{tabular}

The effect of seed treatment on energy and germination is slightly different than on sprouts, it is more environmentally friendly with delivery of the drug to the object, but at the same time, the effect of the drug may be lost due to different conditions or begins to act during active growth in the subsequent phases of ontogenesis to the phase of tillering. herefore we checked influence of preparations by treatment of already germinated seed during one day with appeared rudimentary roots and sprout. Regularity in the effect of preparations is the same as in pre-sowing seed treatment, but the effect is more pronounced and noticeable visually when examining the cups with plants. The reaction of plants to drug overdose, was initially expressed by bloating of roots, and then a lag in the growth of triticale seedlings. When analyzed on day 7 , the number of normally developed plants was evaluated for most drugs was reduced relative to the control and those drugs that had a positive effect the number of normally developed plants was at the level of control or exceeded. Sprout length in the experimental variants ranged from 9 to $15 \mathrm{~cm}$, with an increase relative to control observed for the preparations $\mathrm{Mn}, 10 \mathrm{ml} / \mathrm{t}, \mathrm{Ca}, 10 \mathrm{ml} / \mathrm{t}, \mathrm{Mo}, 50$ $\mathrm{ml} / \mathrm{t}$, Titan M, $50 \mathrm{ml} / \mathrm{t}$, biogenic Fe, $5 \mathrm{ml} / \mathrm{t}$, Boron $5 \mathrm{mg} / \mathrm{g}+\mathrm{GC}(10 \%), 1 \mathrm{ml} / \mathrm{t}$, Potassium, $1000 \mathrm{ml} / \mathrm{t}$ of which the variants with application, Boron $5 \mathrm{mg} / \mathrm{g}+\mathrm{GC}(10 \%), 1 \mathrm{ml} / \mathrm{t}$, Potassium, $1000 \mathrm{ml} / \mathrm{t}$ had the greatest and significant effect, where the increase in length relative to control was $1.0-3.2 \mathrm{~cm}$ or $7.8-25 \%$. Moreover, treatment of seeds with potassium did not show its effect on seed germination activity, but treatment of the germinating organism showed a significant effect on the growth functions of the young plant. When the sprout length increased, its weight increased by $0.5-1.4 \mathrm{~g}$ or $6-8 \%$ (Table 2).

Table 2. Development of triticale plants when treating daily seedlings with elements.

\begin{tabular}{|c|c|c|c|c|}
\hline № & Option & $\begin{array}{c}\text { Normally developed } \\
\text { plants, \% }\end{array}$ & $\begin{array}{c}\text { Sprout length total / } \\
\text { normally developed } \\
\text { plants, cm }\end{array}$ & $\begin{array}{c}\text { Sprout } \\
\text { weight per } \\
\text { 100 plants, } \mathbf{g}\end{array}$ \\
\hline 1 & $\begin{array}{c}\mathrm{Fe}_{3} \mathrm{O}_{4},-5 \mathrm{ml} / \mathrm{t}+\mathrm{SiO}, 2 \mathrm{ml} / \mathrm{t}+ \\
\text { nitrogen, } 5 \mathrm{ml} / \mathrm{t}+\text { Potassium, } \\
\mathrm{ml} / \mathrm{t}\end{array}$ & 85 & $11,71 / 12,61$ & 9,05 \\
\hline 2 & Copper $2-50 \mathrm{ml} / \mathrm{t}$ & 85 & 12,70 & 9,47 \\
\hline
\end{tabular}




\begin{tabular}{|c|c|c|c|c|}
\hline 3 & $\mathrm{Fe}_{3} \mathrm{O}_{4}-100 \mathrm{ml} / \mathrm{t}$ & 90 & $11,65 / 12,64$ & 9,10 \\
\hline 4 & Mn $3-10 \mathrm{ml} / \mathrm{t}$ & 90 & $12,27 / 13,31$ & 9,73 \\
\hline 5 & Ca $5-10 \mathrm{ml} / \mathrm{t}$ & 80 & 13,59 & 10,43 \\
\hline 6 & Са 5 - 50 мл/т & 80 & 13,00 & 9,81 \\
\hline 7 & Bio $\mathrm{Fe}-5$ мл/т & 90 & 13,58 & $\mathbf{9 , 8 8}$ \\
\hline 8 & $\operatorname{Titan} \mathrm{M}-50 \mathrm{ml} / \mathrm{t}$ & 95 & $12,5 / 13,38$ & 9,63 \\
\hline 9 & Mo $2-10 \mathrm{ml} / \mathrm{t}$ & 95 & 12,81 & 9,15 \\
\hline 10 & Mo $2-50 \mathrm{ml} / \mathrm{t}$ & 95 & $13,00 / 13,64$ & 9,00 \\
\hline 11 & Zn 2000 ppm - 10 ml/t & 90 & $9,25 / 9,88$ & 5,85 \\
\hline 12 & $\begin{array}{l}\text { Magnesium }-20 \mathrm{mg} / \mathrm{ml}+\mathrm{PVP} \\
\text { particles }<10 \mathrm{~nm}, 1 \mathrm{ml} / \mathrm{t}\end{array}$ & 90 & 12,60 & 8,94 \\
\hline 13 & $\begin{array}{c}4 \text { Boron }-5 \mathrm{mg} / \mathrm{g}+\mathrm{GC}(10 \%), 1 \\
\mathrm{ml} / \mathrm{t}\end{array}$ & 90 & $13,74-14,11$ & 9,55 \\
\hline 14 & $\begin{array}{l}\mathrm{P}-10 \mathrm{mg} / \mathrm{g}+\mathrm{K} 12 \mathrm{mg} / \mathrm{g}+\mathrm{PVP} \\
15 \%+\mathrm{Ag}-\mathrm{C} 0.5 \mathrm{mg} / \mathrm{g}-10 \mathrm{ml} / \mathrm{t}\end{array}$ & 90 & 13,11 & 9,00 \\
\hline 15 & $\begin{array}{c}\mathrm{N}-4 \mathrm{M \Gamma} / \Gamma+\mathrm{P}-9 \mathrm{M \Gamma} / \Gamma+\mathrm{PVP} 15 \\
\%+\mathrm{Ag}-\mathrm{C}-0,5 \mathrm{M} / \Gamma-10 \mathrm{MI} / \mathrm{T}\end{array}$ & 95 & 11,42 & 7,52 \\
\hline 16 & Potassium $-500 \mathrm{ml} / \mathrm{t}$ & 100 & 12,9 & 8,8 \\
\hline 17 & Potassium-1000 ml/t & 95 & $14,33 / 15,96$ & 9,62 \\
\hline 18 & Nitrogen $-10 \mathrm{ml} / \mathrm{t}$ & 90 & 12,69 & 8,61 \\
\hline \multirow[t]{2}{*}{19} & Control (water)-6 ml & 95 & 12,74 & 9,0 \\
\hline & difference & $+-3,5$ & $+-0,9$ & $+-0,15$ \\
\hline
\end{tabular}

In the field study of biogenic iron application the following variants of seed preparation were carried out 1 . Chemical dressing with insecticide and fertilizer, 2. Control without treatment, 3. Chemical seed dressing + biogenic Fe, 4. Chemical dressing $+\mathrm{SiO}_{2}, 5$. Dressing agent $+\mathrm{SiO} 2+$ biogenic $\mathrm{Fe}$ and overlapping preparations with biogenic iron and silicon during vegetation. Treated seeds after 12 days, were put for germination in rolls to evaluate the effect of the applied preparations on the development of germinating organs and suppression of seed infection. Seeds of spring wheat variety Grenada, were selected with initial, weak germination to understand and evaluate the effects of the applied agents on plant development. Seed germination after treatment with the means taken for the test compared to the control ranged from $60-79 \%$, the effect of the preparation with iron on reducing germination or inhibition of seed germination processes was noted. According to the authors, oxidative stress can be caused by nanoparticles of many metals (silver, gold, iron), ferrites, as well as oxides of zinc, nickel, copper, iron, titanium, silicon and comprehensive studies revealing the mechanisms of their phytotoxic properties of transition metal nanoparticles (iron, copper and nickel) in comparison with their oxide forms have not been conducted before [22]. Reduced germination of wheat and barley seeds was also recorded in the studies of Korotkova A.M. et al, after treatment with 5-10-2 mg/1 Fe3O4 by $13 \%$ (significantly compared to control at $p<0,05$ ) [23]. High stimulating effect was observed on germinated plants in variants where iron-containing nanoparticles were present, which was expressed in a significant increase in main root growth compared to control and chemical dresser by 1.2-1.8 $\mathrm{cm}$ in length and by 0.6-0.9 $\mathrm{g}$ increase in root weight. Seed germination when treated with biogenic iron decreased by $4-10 \%$ relative to other options, adding silicon in the mixture to the dressing and biogenic iron leveled the negative impact of the preparation on seed germination. Application of iron most likely, should be limited for seed treatment because it inhibits the emergence of sprouts, but at the 
same time more possible and positive effect has a treatment of plants during the growing season especially in the period of active growth on the green parts of the plant (Table 3 ).

Table 3. Germination and development of germ organs of spring wheat during seed treatment.

\begin{tabular}{|c|c|c|c|c|c|c|c|}
\hline № & Option & $\begin{array}{l}\text { Germinati } \\
\text { on, } \%\end{array}$ & $\begin{array}{c}\text { Root } \\
\text { length, } \\
\text { cm }\end{array}$ & $\begin{array}{l}\text { Weight } \\
\text { of roots, } \\
\quad g\end{array}$ & $\begin{array}{l}\text { Coleoptile } \\
\text { length, cm }\end{array}$ & $\begin{array}{c}\text { Sprout } \\
\text { length, } \\
\text { cm }\end{array}$ & $\begin{array}{c}\text { Weight } \\
\text { of } \\
\text { sprouts, } \\
\text { g }\end{array}$ \\
\hline \multirow[b]{2}{*}{1} & \multirow{2}{*}{$\begin{array}{l}\text { Chemical+ } \\
\text { Insecticide+ } \\
\text { Fertilizer }\end{array}$} & \multirow[b]{2}{*}{$(72-82) 77$} & 12,99 & 1,84 & 4,75 & 11,37 & 3,62 \\
\hline & & & $+0,49$ & $+0,13$ & $-2,0$ & $+1,72$ & $-0,08$ \\
\hline \multirow{2}{*}{2} & \multirow{2}{*}{$\begin{array}{l}\text { Control (no } \\
\text { treatment) }\end{array}$} & \multirow{2}{*}{$(73-86) 78$} & 12,5 & 1,71 & 6,75 & 9,65 & 3,70 \\
\hline & & & - & - & - & - & - \\
\hline \multirow{2}{*}{3} & \multirow{2}{*}{$\begin{array}{l}\text { Dressing agent } \\
+ \text { biogenic } \mathrm{Fe}-1 \\
\mathrm{ml}\end{array}$} & \multirow{2}{*}{$(66-76) 61$} & 14,1 & 2,67 & 4,1 & 7,4 & 2,73 \\
\hline & & & $+1,6$ & $+0,96$ & $-2,65$ & $-2,25$ & $-0,97$ \\
\hline \multirow{2}{*}{4} & \multirow{2}{*}{$\begin{array}{l}\text { Etchant }+\mathrm{SiO}_{2}, \\
1 \mathrm{ml}\end{array}$} & \multirow{2}{*}{$(74-84) 79$} & 14,3 & 2,54 & 4,75 & 9,3 & 3,39 \\
\hline & & & $+1,8$ & $+0,83$ & $-2,0$ & $-0,35$ & $-0,31$ \\
\hline \multirow[b]{2}{*}{5} & \multirow{2}{*}{$\begin{array}{l}\text { Etchant }+\mathrm{SiO}_{2}, \\
1 \mathrm{ml}+\text { biogenic } \\
\mathrm{Fe}-1 \mathrm{ml}\end{array}$} & \multirow[b]{2}{*}{$(72-84) 78$} & 13,7 & 2,34 & 5,0 & 9,7 & 3,56 \\
\hline & & & $+1,2$ & $+0,63$ & $-1,75$ & $+0,05$ & $-0,14$ \\
\hline
\end{tabular}

Analysis of seed infestation was carried out according to the three main infections causing seedlings rotting and root rot, so seed infestation included fungi p. Alternaria - 10$12 \%$, Fusarium p. - 2-7\%, Bipolaris sorokiniana - 0-2\%.

We note that this amount of seed infection is insignificant and does not exceed the EPV (economic threshold). The efficiency of seed treatment and reduction of infection on seeds when treated with a chemical seed dressing was $100 \%$. In the analysis, the residual amount of infection was noted only for Fusarium type and when treated with a seed dressing with iron and silicon, the reduction was up to $90-95 \%$. Plant root rot begins to appear depending on the presence of soil infection, weather and agrotechnical conditions conducive to its development. Manifestation of the disease is possible in the initial period of vegetation and is important for the growth and development of the crop, which determines the decrease in yield depending on the development of the disease on 1 plant and distribution in the field.

During the tillering phase root rot development of wheat plants from untreated seeds was $1.4 \%$, spreading was $5.6 \%$ and during the growing season the damage increased 3 -fold. Application of a chemical dressing protected plants against rots by $100 \%$, during the initial phase of development and by the end of vegetation the effectiveness against disease development was $78-84 \%$, spreading by $71-79 \%$. Inclusion of preparations based on iron and silicon in the mixture to chemical dressing reduced the efficiency of chemical dressing by $18-22 \%$ during the initial vegetation period and before harvesting the efficiency of the intake decreased by $16-22 \%$ for chemical dressing, by $30 \%$ for iron and by $38-40 \%$ for silicon (Table 4).

Table 4. Effectiveness of the method against root rot, $\%$.

\begin{tabular}{|c|c|c|c|c|c|c|}
\hline \multirow{2}{*}{ № } & \multicolumn{3}{|c|}{ The tillering phase } & \multicolumn{3}{c|}{ Before cleaning } \\
\cline { 2 - 7 } & $\begin{array}{c}\text { Development, } \\
\mathbf{\%}\end{array}$ & $\begin{array}{c}\text { Distribution, } \\
\mathbf{\%}\end{array}$ & $\begin{array}{c}\text { Efficiency, } \\
\mathbf{\%}\end{array}$ & $\begin{array}{c}\text { Development, } \\
\mathbf{\%}\end{array}$ & $\begin{array}{c}\text { Distribution, } \\
\mathbf{\%}\end{array}$ & $\begin{array}{c}\text { Efficiency, } \\
\mathbf{\%}\end{array}$ \\
\hline 1 & 0 & 0 & 100 & $0,72-1,01$ & $2,90-4,05$ & $84,42-78,2$ \\
\hline 2 & 1,4 & 5,62 & - & 4,65 & 13,95 & - \\
\hline 3 & 0,25 & 0,99 & 82,38 & 1,35 & 4,59 & 70,96 \\
\hline 4 & 0,25 & 1,01 & 82,02 & 1,76 & 5,04 & 62,15 \\
\hline 5 & 0,3 & 0,96 & 78,5 & 1,42 & 4,66 & 69,46 \\
\hline
\end{tabular}


At the end of the growing season when treated with the standard mixture option 1 (fungicidal + insecticidal etchant + fertilizer) the effectiveness against the development of $78-84 \%$, the spread of $71-79 \%$, which is $8-17 \%$ higher in relation to the application of the etchant in the mixture of iron, silicon. There was some effect on the development of vegetative mass during the growing season, the phase of the end of tillering (30-31) there was a 2-6 cm lag in the length of the plant by the variants of biogenic iron in mixture with a chemical dressing.

Yield of the crop is the main indicator of assessment of technological methods. Application of preparations containing biogenic iron and silicon to the variants of experience with seed pretreatment obtained the following effect of these preparations on the yield. In the control variant without seed preparation, but with treatment against weeds, the yield was $2.4 \mathrm{t} / \mathrm{ha}$, the use of plant protection products increased the data on yield by 0.4 $\mathrm{t} / \mathrm{ha}$, this in a year when there were no epiphytoties of leaf-rolling diseases. The application of biogenic iron resulted in a yield increase of $0.5 \mathrm{t} / \mathrm{ha}$ at a single application during the growing season in the late earing phase, and the application of iron during tillering and earing increased the yield increase to $0.63 \mathrm{t} / \mathrm{ha}$. A significant difference between the variants is the application of biogenic iron in all key phases in relation to the control and the standard scheme of crop protection (Table 5).

Table 5. Crop yield, t/ha.

\begin{tabular}{|l|c|c|c|}
\hline \multicolumn{1}{|c|}{ Option } & \multirow{2}{*}{$\begin{array}{c}\text { Average, } \\
\text { t/ha }\end{array}$} & \multicolumn{2}{|c|}{ +- for oversight } \\
\cline { 3 - 4 } & t/ha & $\mathbf{\%}$ \\
\hline $\begin{array}{l}\text { 2. Control (without seed treatment and without } \\
\text { fungicides) }\end{array}$ & 2,38 & - & - \\
\hline $\begin{array}{l}\text { 1. Control (with seed dressing and plant protection } \\
\text { products during vegetation) }\end{array}$ & 2,78 & 0,4 & 16,8 \\
\hline $\begin{array}{l}\text { 3. Dressing agent, 0.8 L + biogenic Fe, 1 ml } \\
\text { (seeds) + biogenic Fe, 1 ml (earing) }\end{array}$ & 2,94 & 0,56 & 23,5 \\
\hline $\begin{array}{l}\text { 4. Dressing agent, 0.8 L + Silicon, 1 ml (seeds) + } \\
\text { Silicon, 1 ml (tillering) + Silicon, 1 ml (earing) }\end{array}$ & 2,80 & 0,42 & 17,6 \\
\hline $\begin{array}{l}\text { 5. Dressing agent, 0,8 1 + Silicon, 1 ml + Biogenic } \\
\text { Fe, 1 ml (seeds) + Silicon 1 ml + Biogenic Fe, 1 } \\
\text { ml (tillering) + Silicon, 1 ml + Biogenic Fe, 1 ml } \\
\text { (earing) }\end{array}$ & 3,01 & 0,63 & 26,4 \\
\hline NSR & & 0,22 & \\
\hline
\end{tabular}

According to the variants of micronutrients application the reliable yield increase is marked at application of biogenic iron during vegetation by $0,63 \mathrm{t} / \mathrm{ha}$ to the control without seed treatment and $0,16-0,23 \mathrm{t} / \mathrm{ha}$ to the standard scheme of protection. The results show that, despite the negative impact on the laboratory germination, preparations of biogenic iron can be applied in the phase of tillering and earing, but the highest impact is a single application in the phase of earing, the difference between the option № 3 and № 5 is 0.07 $\mathrm{t} / \mathrm{ha}$ which is not significant, but more costly in technical terms and volume of the application of the drug.

\section{Conclusions}

Positive effect on germination energy and germination of spring triticale seeds showed variants with pretreatment of seeds with $\mathrm{Cu}, \mathrm{Mn}$, Mo, biogenic Fe, Titan $\mathrm{M}$, where the increase in indicators was $4-10 \%$, of which a clear high effect was by preparations Titan $\mathrm{M}$ in the rate $500 \mathrm{ml} / \mathrm{t}(+6+7 \%)$, Mo molybdenum in the rate $10-50 \mathrm{ml} / \mathrm{t}(+10+7 \%)$. 
Analysis of triticale plants with pretreatment of daily seedlings showed the effect of the studied preparations on sprout development. Here the effect on inhibition of growth is noted, but the preparations which had a positive effect on germination, also affected the treatment of live plants. Sprout length was increased relative to control by $\mathrm{Mn}, 10 \mathrm{ml} / \mathrm{t}$; Ca, $10 \mathrm{ml} / \mathrm{t}$; Mo, $50 \mathrm{ml} / \mathrm{t}$; Titan M, $50 \mathrm{ml} / \mathrm{t}$; biogenic Fe, $5 \mathrm{ml} / \mathrm{t}$; Boron $5 \mathrm{mg} / \mathrm{g}+\mathrm{GC}(10 \%), 1$ $\mathrm{ml} / \mathrm{t}$; Potassium, $1000 \mathrm{ml} / \mathrm{t}$. Of these, the variants with Boron $5 \mathrm{mg} / \mathrm{g}+\mathrm{GC}(10 \%), 1 \mathrm{ml} / \mathrm{t}$; Potassium, $1000 \mathrm{ml} / \mathrm{t}$ had the greatest and significant impact, where the increase in sprout length relative to the control was $1.0-3.2 \mathrm{~cm}$ or $7.8-25 \%$ and in weight by $0.5-1.4 \mathrm{~g}$ or 6 $8 \%$.

Seed treatments reduced germination by iron preparations, promoted root growth by iron and silicon increasing the length by $1.6 \mathrm{~cm}$ or $12 \%$. Reduced the retardant effect of dressing when treated with a mixture of silicon and fertilizer by $20 \%$. Treatment with a complex mixture of dressing with $\mathrm{SiO} 2$ silicon preserved sprout development at the control level. The other options reduced the growth of the aboveground part of the plant. The effectiveness of preparations against seed infection in the mixture with iron and silicon decreased from the effective action of chemical dressing in $100 \%$ to $90-95 \%$.

Application of chemical dressing reduced the lesion of root rot at the beginning of the growing season by $100 \%$ and at the end of the growing season by $71-84 \%$. Adding iron and silicon to the mixture reduced the effectiveness against root rot during the growing season by $16-30 \%$.

Greater dependence of the yield and, accordingly, the gain was observed on the factor of application of the elements of technology. The application of biogenic iron by seeds and by vegetation, in the most part influenced the treatment by vegetation, which kept the yield at the level of 2.94-3.01 t/ha, and determined the greater influence of the application of biogenic iron in the earing phase as a separate element of technology, and in a tank mixture with fungicides.

As a result, the use of nanoparticles of macro- and micronutrients used in the study and showed a positive effect is possible both for pre-sowing treatment of seeds and during the growing season in the phase of tillering, and biogenic iron greater effect when treated in the earing phase.

\section{Acknowledgements}

The work was carried out according to state order No. 121041600036-6

\section{References}

1. T. A. Soroka, Proceedings of OGAU 2 (64), 21-24 (2017)

2. N.V. Dolgopolova, Bulletin of the Kursk State Agricultural Academy 1, 48-52(2019)

3. L.M. Anikina, O.R. Udalova, G.G. Panova, Proceedings of the V International Scientific and Practical Conference, Simferopol IT "ARIAL", 13-15 (2020)

4. M.F. Amirov, Vestnik of Kazan GAU 4(47), 5-7 (2017)

5. N.V. Goman, V.V. Popova, I.A. Bobrenko, A.A. Gaidar, Vestnik of Omsk State Agrarian University 4 (36), 6-12(2019)

6. E.M. Chirko, V.G. Timoshchenko, Collection of Scientific Works, 193-201 (Republic of Belarus, Grodno, 2019)

7. V.V. Matichenkov, E.A. Bocharnikova, Plant Mineral Nutrition and Pesticide Management. Amsterdam: Kluwer Academic Publishers 2, 217-239 (2004)

8. I.V. Slastya, Agrochemistry 10, 51-59 (2012) 
9. D.V. Syshchikov, S.A. Prikhodko, I.A. Udodov, O.V. Syshchikova, Industrial Botany, 17, 37-43 (2017)

10. N.G. Vlasenko, O.I. Teplyakova, A.V. Dushkin, Siberian Bulletin of Agricultural Science 49(6), 5-15 (2019)

11. A.N. Kshnikatkina, I.G. Rusyaev, Niva Povolzhye, 1 (46), 41-45 (2018)

12. Premysl Landa, Plant Physiology and Biochemistry 161, 12-24 (2021)

13. Prabha Rai-Kalal Anjana Jajoo, Plant Physiology and Biochemistry 160, 341-351 (2021)

14. V.V. Semenov, N.V. Zolotareva, B.I. Petrov, N.M. Lazarev, A.O. Syubaeva, N.A. Kodochilova, E.Y. Geiger, E.N. Razov, Bulletin of South Ural State University. Series: Chemistry 11 (3), 5-16 (2019)

15. N.Yu. Garmash, P.M. Polityko, G.A. Garmash, S.Yu. Novikov, A.V. Solomatin, Agrochemical Bulletin 5, 38-40 (2020)

16. I.R. Wildflush, A.A. Kuleshova, Bulletin of the Belarusian State Agricultural Academy 2, 71-76 (2020)

17. A.A. Khoroshilov, S.A. Frolova Materials of the International Scientific and Practical Conference of Young Scientists and Specialists. Orel, December 14-15, 191-195 (2017)

18. E.Sh. Zakirov, R.N. Sagitova, I.A. Gaisin, Agroecology, 2-2 (4), 39-43 (2015)

19. V.V. Popova, N.V. Goman, M.A. Kireeva, Proceedings of the XI National ScientificPractical Conference (with international participation), 459-464 (Omsk, 2020)

20. V.I. Nikitishen. L.M. Terekhova, V.I. Lichko, Agrochemistry 8, 35-43 (2007)

21. GOST 12038-84. Seeds of agricultural crops. Methods of analysis. Sb. of State Standards, 47 (Moscow Publishing house of standards, 2004)

22. A.M. Korotkova, S.V. Lebedev, F.G. Kayumov, E.A. Sizova, Agricultural Biology 52, 1, 172-182 (2017)

23. A.M. Korotkova, L.V. Galaktionova, O.V. Kvan, N.A. Terekhova, V.A. Orlova, M.I. Petrov, Problems of Regional Ecology 4, 31-35 (2018) 